Article

\title{
Optimization of Operating Conditions for Electrochemical Decolorization of Methylene Blue with $\mathrm{Ti} / \alpha-\mathrm{PbO}_{2} / \beta-\mathrm{PbO}_{2}$ Composite Electrode
}

\author{
Md. Ashraful Islam Molla 1,*D, Genta Yanagi ${ }^{2}$, Mai Furukawa ${ }^{2}$, Ikki Tateishi ${ }^{3}$ (D) Hideyuki Katsumata $^{2}$ (D) \\ and Satoshi Kaneco ${ }^{2, *(D)}$ \\ 1 Department of Applied Chemistry and Chemical Engineering, Faculty of Engineering and Technology, \\ University of Dhaka, Dhaka 1000, Bangladesh \\ 2 Department of Chemistry for Materials, Faculty of Engineering, Mie University, Mie, Tsu 514-8507, Japan; \\ 419m355@m.mie-u.ac.jp (G.Y.); maif@chem.mie-u.ac.jp (M.F.); hidek@chem.mie-u.ac.jp (H.K.) \\ 3 Environmental Preservation Center, Mie University, Mie, Tsu 514-8507, Japan; tateishi@gecer.mie-u.ac.jp \\ * Correspondence: ashraful.acce@du.ac.bd (M.A.I.M.); kaneco@chem.mie-u.ac.jp (S.K.); \\ Tel.: +88-015-5235-9706 (M.A.I.M.); +81-59-231-9427 (S.K.)
}

check for

updates

Citation: Molla, M.A.I.; Yanagi, G.; Furukawa, M.; Tateishi, I.; Katsumata, H.; Kaneco, S. Optimization of Operating Conditions for Electrochemical Decolorization of Methylene Blue with $\mathrm{Ti} / \alpha-\mathrm{PbO}_{2} / \beta-\mathrm{PbO}_{2}$ Composite Electrode. J. Compos. Sci. 2021, 5, 117. https://doi.org/10.3390/jcs5050117

Academic Editor: Patrizia Bocchetta

Received: 31 March 2021

Accepted: 23 April 2021

Published: 27 April 2021

Publisher's Note: MDPI stays neutral with regard to jurisdictional claims in published maps and institutional affiliations.

Copyright: (C) 2021 by the authors. Licensee MDPI, Basel, Switzerland. This article is an open access article distributed under the terms and conditions of the Creative Commons Attribution (CC BY) license (https:/ / creativecommons.org/licenses/by/ $4.0 /)$.

\begin{abstract}
PbO}_{2}$ was introduced into the intermediate layer of an electrode to prevent the separation of the electrodeposited layer and maintain oxidizing power. The resulting $\mathrm{Ti} / \alpha-\mathrm{PbO}_{2} / \beta-\mathrm{PbO}_{2}$ composite electrode was applied to the electrochemical decolorization of methylene blue (MB) and the operating conditions for $\mathrm{MB}$ decolorization with the $\mathrm{Ti} / \alpha-\mathrm{PbO}_{2} / \beta-\mathrm{PbO}_{2}$ electrode were optimized. The morphology, structure, composition, and electrochemical performance of $\mathrm{Ti} / \alpha-\mathrm{PbO}_{2}$ and $\mathrm{Ti} / \alpha-\mathrm{PbO}_{2} / \beta-\mathrm{PbO}_{2}$ anode were evaluated using scanning electron microscopy (SEM), $\mathrm{X}$-ray diffraction (XRD), X-ray photoelectron spectroscopy (XPS), cyclic voltammetry (CV), and electrochemical impedance spectroscopy (EIS). The optimum operating parameters for the electrochemical decolorization of $\mathrm{MB}$ at $\mathrm{Ti} / \alpha-\mathrm{PbO}_{2} / \beta-\mathrm{PbO}_{2}$ composites were as follows: $\mathrm{Na}_{2} \mathrm{SO}_{4}$ electrolyte $0.05 \mathrm{~g} \mathrm{~L}^{-1}$, initial concentration of $\mathrm{MB} 9 \mathrm{mg} \mathrm{L}^{-1}$, cell voltage $20 \mathrm{~V}$, current density $0.05-0.10 \mathrm{~A} \mathrm{~cm}^{-2}$, and $\mathrm{pH}$ 6.0. $\mathrm{MB}$ dye could be completely decolorized with $\mathrm{Ti} / \alpha-\mathrm{PbO}_{2} / \beta-\mathrm{PbO}_{2}$ for the treatment time of less than one hour, and the dye decolorization efficiency with $\mathrm{Ti} / \alpha-\mathrm{PbO}_{2} / \beta-\mathrm{PbO}_{2}$ was about 5 times better, compared with those obtained with $\mathrm{Ti} / \alpha-\mathrm{PbO}_{2}$.
\end{abstract}

Keywords: electrochemical decolorization; methylene blue; $\mathrm{PbO}_{2}$ electrode; composite; purification

\section{Introduction}

Recently water pollution by dyes in rivers and oceans has become a very serious global environmental problem, since about $20 \sim 50 \%$ of the applied dyes in textile industry remain in the aqueous phase [1,2]. To solve this problem, we need to treat dyes contained in domestic wastewater and industrial waste. In particular, synthetic dyes contain substances that are toxic and carcinogenic to the human body and can be harmful if taken into the body $[1,2]$.

Various advanced oxidation processes (AOPs) for decomposing or utilizing wastewater containing synthetic dyes have been reported, such as ozonolytic oxidation $[3,4]$, Fenton/electro-Fenton processes [5,6], photocatalysis [7,8], electrocoagulation [9], and electrochemical oxidation $[10,11]$. Among them electrochemical oxidation has features such as easy operability, low environmental load, safety, and high energy efficiency, it is regarded as one of the technologies of advanced oxidation treatment of wastewater containing toxic organic pollutants [10,11].

Ti-based $\mathrm{PbO}_{2}$ and boron-doped diamond (BDD) electrodes have a large oxygen generation overvoltage [12-16]. The Ti-based $\mathrm{PbO}_{2}$ is one of the promising electrode materials, because it can anodize harmful organic substances in wastewater and decompose them efficiently and has the merits of low cost. Methylene blue (MB), which is intensively used 
in textile industries, is a non-biodegradable, synthetic, and hazardous organic compound. It is also used as a medicine to treat methemoglobinemia. Common side effects include headache, vomiting, confusion, shortness of breath, hypertension, and so on [17-19]. Firstly, we have tried to modify the Ti-based $\mathrm{PbO}_{2}$ electrodes for the electrochemical remediation of MB wastewater [20]. However, there is little information on the optimum operating conditions for the electrochemical decolorization of $\mathrm{MB}$ with Ti-based $\beta-\mathrm{PbO}_{2}$ electrode. Therefore, the present work has mainly dealt with the optimization of operating conditions for the electrochemical degradation of $\mathrm{MB}$ at $\mathrm{Ti} / \alpha-\mathrm{PbO}_{2} / \beta-\mathrm{PbO}_{2}$ electrode. Moreover, the morphology, structure, composition, and electrochemical performance of $\mathrm{Ti} / \alpha-\mathrm{PbO}_{2} / \beta-$ $\mathrm{PbO}_{2}$ were evaluated by using scanning electron microscopy (SEM), X-ray diffrac-tion (XRD), X-ray photoelectron spectroscopy (XPS), cyclic voltammetry (CV), and electrochemical impedance spectroscopy (EIS).

\section{Materials and Methods}

\subsection{Chemicals and Materials}

Titanium, copper, and platinum plates (purity: 99.9\%, thickness: $1.0 \mathrm{~mm}$ ) were purchased from Nilaco Co, Ltd. (Tokyo, Japan). Acetone (99.5\%), $\mathrm{HNO}_{3}(70 \%)$, and $\mathrm{NaOH}$ (97\%) were obtained from Nacalai Tesque Co, Ltd. (Kyoto, Japan). $\mathrm{PbO}(99.5 \%), \mathrm{Pb}\left(\mathrm{NO}_{3}\right)_{2}$ (99.5\%), $\mathrm{Cu}\left(\mathrm{NO}_{3}\right)_{2}(99.9 \%), \mathrm{Na}_{2} \mathrm{SO}_{4}(99 \%)$, and methylene blue $\left(\mathrm{C}_{6} \mathrm{H}_{18} \mathrm{ClN}_{3} \mathrm{~S}, 98.5 \%\right)$ were obtained from FUJIFILM Wako Pure Chemical Corp. (Osaka, Japan). All of other chemicals were analytic grade. All of the solutions were prepared with pure deionized water.

\subsection{Preparation of Electrodes}

Before the coating, titanium plates $(30 \times 10 \mathrm{~mm}, 0.10 \mathrm{~mm}$ thickness, $99.5 \%)$ were pretreated by sandblasting and ultrasonic cleaning in acetone and ultrapure water [21]. We used an $\mathrm{H}$-type cell for the electrodeposition. The $\alpha-\mathrm{PbO}_{2}$ layer was electrochemically deposited on the titanium plate in an anolyte $(50 \mathrm{~mL})$ consisting of $0.1 \mathrm{~mol} \mathrm{~L}{ }^{-1} \mathrm{PbO}_{2}$ and $3.5 \mathrm{~mol} \mathrm{~L}^{-1} \mathrm{NaOH}$ with a catholyte $(50 \mathrm{~mL})$ of $3.5 \mathrm{~mol} \mathrm{~L}^{-1} \mathrm{NaOH}$ at $5 \mathrm{~mA} \mathrm{~cm}^{-2}$ for $2 \mathrm{~h}$ [22]. Finally, the electro-deposition of the $\beta-\mathrm{PbO}_{2}$ layer was performed on the $\alpha$ $\mathrm{PbO}_{2}$ layer in $0.3 \mathrm{~mol} \mathrm{~L}^{-1} \mathrm{~Pb}\left(\mathrm{NO}_{3}\right)_{2}$ anolyte $(50 \mathrm{~mL})$ with $0.3 \mathrm{~mol} \mathrm{~L}{ }^{-1} \mathrm{Cu}\left(\mathrm{NO}_{3}\right)_{2}$ catholyte

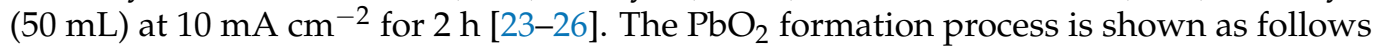
(Equations (1)-(4)):

$$
\begin{gathered}
\mathrm{H}_{2} \mathrm{O} \rightarrow \bullet \mathrm{OH}+\mathrm{H}^{+}+\mathrm{e}^{-} \\
\mathrm{Pb}^{2+}+\bullet \mathrm{OH} \rightarrow \mathrm{Pb}(\mathrm{OH})^{2+} \\
\mathrm{Pb}(\mathrm{OH})^{2+}+\mathrm{H}_{2} \mathrm{O} \rightarrow \mathrm{Pb}(\mathrm{OH})_{2}{ }^{2+}+\mathrm{H}^{+}+\mathrm{e}^{-} \\
\mathrm{Pb}^{4+}+2 \mathrm{H}_{2} \mathrm{O} \rightarrow \mathrm{PbO}_{2}+4 \mathrm{H}^{+}
\end{gathered}
$$

\subsection{Characterization}

The surface morphology of each layer of the electrodes was investigated with Hitachi S-4000 scanning electron microscopy (SEM). XRD was performed using X-ray diffraction (XRD, Ultima IV, horizontal sample type, RIGAKU Corp., Tokyo, Japan) to analyze the crystal structure that makes up each electrode. The chemical composition and state of the active layer of electrodes were investigated using a Quantera SXM X-ray photoelectron spectrometer (XPS, ULVAC-PHI, Chanhassen, MN, USA) using $\mathrm{Al} \mathrm{K}_{\alpha}$ radiation. All of the electrochemical measurements, including the electrochemical impedance spectroscopy (EIS), were performed in an electrochemical workstation equipped with a three-electrode cell system (VersaSTAT 3F; AMETEK Scientific Instruments, Berwyn, PA, USA). The working electrode was the prepared $\mathrm{PbO}_{2}$ electrode. A platinum plate and a silver-silver chloride electrode $(\mathrm{Ag} / \mathrm{AgCl}$ sat. $\mathrm{KCl})$ were used as the counter and reference electrodes, respectively.

\subsection{Electrochemical Decolorization}

Electrochemical decolorization and oxidation of MB was performed in a home-made, divided H-type cell. A Nafion 117-type cation exchange membrane $(0.18 \mathrm{~mm}$ thickness, 
Sigma-Aldrich, St. Louis, MO, USA) was used as the diaphragm. The $9 \mathrm{mg} \mathrm{L}^{-1} \mathrm{MB}$ anolyte solution $(50 \mathrm{~mL})$ contained the $0.50 \mathrm{~mol} \mathrm{~L}^{-1} \mathrm{Na}_{2} \mathrm{SO}_{4}$ supporting electrolyte [1,2]. The catholyte was $0.50 \mathrm{~mol} \mathrm{~L}^{-1} \mathrm{Na}_{2} \mathrm{SO}_{4}$ solution. The prepared $\mathrm{PbO}_{2}$ electrodes and $\mathrm{Pt}$ foil $(30 \times 10 \mathrm{~mm}, 0.10 \mathrm{~mm}$ thickness, $99.98 \%)$ were acted as the anode and cathode, respectively. The cell voltage between anode and cathode was $5 \sim 30 \mathrm{~V}$. The decolorization of MB was measured by UV-Vis absorption spectrometry (UV-2450; Shimadzu, Kyoto, Japan).

\section{Results and Discussion}

\subsection{Characterization of Electrodes}

\subsubsection{XRD Analysis}

XRD was used to analyze and determine the crystal structure of Ti $/ \alpha-\mathrm{PbO}_{2}$ and $\mathrm{Ti} / \alpha-$ $\mathrm{PbO}_{2} / \beta-\mathrm{PbO}_{2}$ composites. Figure 1 shows the XRD patterns of the prepared Ti $/ \alpha-\mathrm{PbO}_{2}$ and $\mathrm{Ti} / \alpha-\mathrm{PbO}_{2} / \beta-\mathrm{PbO}_{2}$ electrodes.

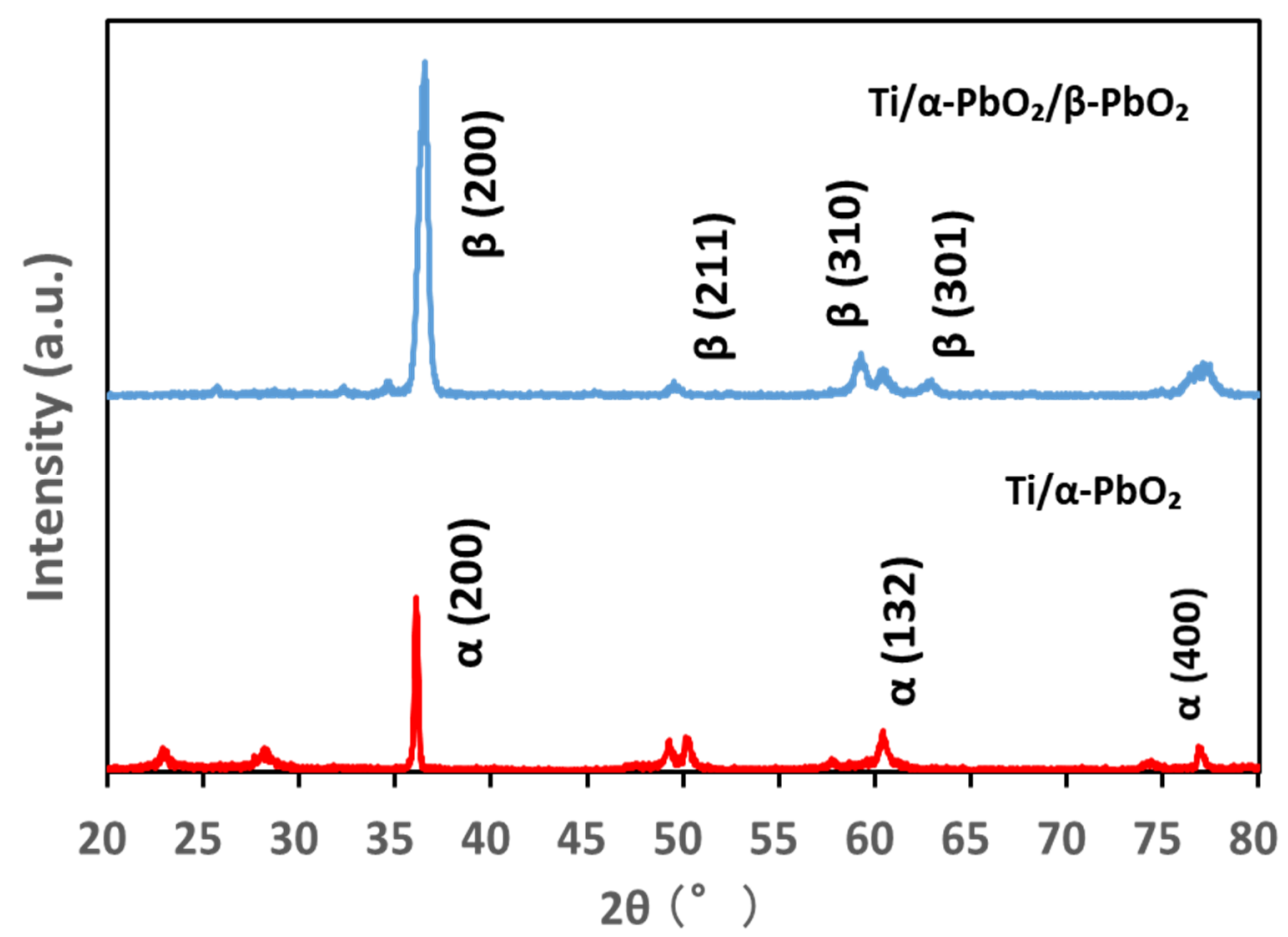

Figure 1. $\mathrm{XRD}$ spectra of $\mathrm{Ti} / \alpha-\mathrm{PbO}_{2}$ and $\mathrm{Ti} / \alpha-\mathrm{PbO}_{2} / \beta-\mathrm{PbO}_{2}$.

The characteristic diffraction peaks of $\alpha-\mathrm{PbO}_{2}$ at $36.06^{\circ}, 60.38^{\circ}$, and $76.96^{\circ}$ correspond to the lattice planes (200), (132), and (400) $[14,27,28]$, whereas those of $\beta-\mathrm{PbO}_{2}$ located at $36.52^{\circ}, 49.4^{\circ}, 59.3^{\circ}$, and $62.8^{\circ}$ correspond to the lattice planes (200), (211), (310) and (311), respectively $[27,29,30]$. The main diffraction peaks of $\alpha-\mathrm{PbO}_{2}$ and $\beta-\mathrm{PbO}_{2}$ both corresponded to the lattice plane (200). Since no unexpected diffraction peak was generated in each pattern, it can be considered that impurities were not generated during the electrode fabrication. The diffraction peaks indicate that the $\beta-\mathrm{PbO}_{2}$ layer is electrochemically deposited on $\alpha-\mathrm{PbO}_{2}$ layer. The XRD peak of Ti $/ \alpha-\mathrm{PbO}_{2} / \beta-\mathrm{PbO}_{2}$ are sharper and stronger compared that with $\mathrm{Ti} / \alpha-\mathrm{PbO}_{2}$, indicating it that the crystallinity of the electrode seems to be improved. Ti $/ \beta-\mathrm{PbO}_{2}$ were not be fabricated because $\beta-\mathrm{PbO}_{2}$ could not be electrodeposited on the Ti.

The half-peak width of the strongest diffraction peaks (200) was employed to calculate the average particle sizes of $\mathrm{PbO}_{2}$ crystals by the Debye-Scherrer formula (Equation (5)).

$$
\mathrm{D}=\frac{K \lambda}{\beta \cos \theta}
$$


where $\mathrm{D}$ is the average particle sizes $(\mathrm{nm}), K$ a constant $(0.89), \lambda$ the wavelength of $X$-ray $(0.15418 \mathrm{~nm}), \beta$ the half-height width of diffraction peak, and $\theta$ the diffraction angle. The average particle sizes of $\mathrm{Ti} / \alpha-\mathrm{PbO}_{2}$ and $\mathrm{Ti} / \alpha-\mathrm{PbO}_{2} / \beta-\mathrm{PbO}_{2}$ electrodes were $0.85 \mathrm{~nm}$ and $0.30 \mathrm{~nm}$, respectively. Thus, there was a distinct difference in average particle sizes as shown in the SEM images.

\subsubsection{SEM Study}

Figure 2 shows SEM images of Ti $/ \alpha-\mathrm{PbO}_{2}$ and $\mathrm{Ti} / \alpha-\mathrm{PbO}_{2} / \beta-\mathrm{PbO}_{2}$ electrodes. The surface of the $\mathrm{Ti} / \alpha-\mathrm{PbO}_{2}$ electrode was coated with fragile cotton-like fine particles (Figure $2 \mathrm{a}$ ). On the other hand, the surface of the $\mathrm{Ti} / \alpha-\mathrm{PbO}_{2} / \beta-\mathrm{PbO}_{2}$ electrode was decorated with dense pyramidal fine particles (Figure $2 \mathrm{c}$ ). Compared with $\mathrm{Ti} / \alpha-\mathrm{PbO}_{2}$ electrode, in $\mathrm{Ti} / \alpha-$ $\mathrm{PbO}_{2} / \beta-\mathrm{PbO}_{2}$ electrode the surface of the fine particles is smoother and denser, and strengthened chemically and physically $[14,28,30]$.

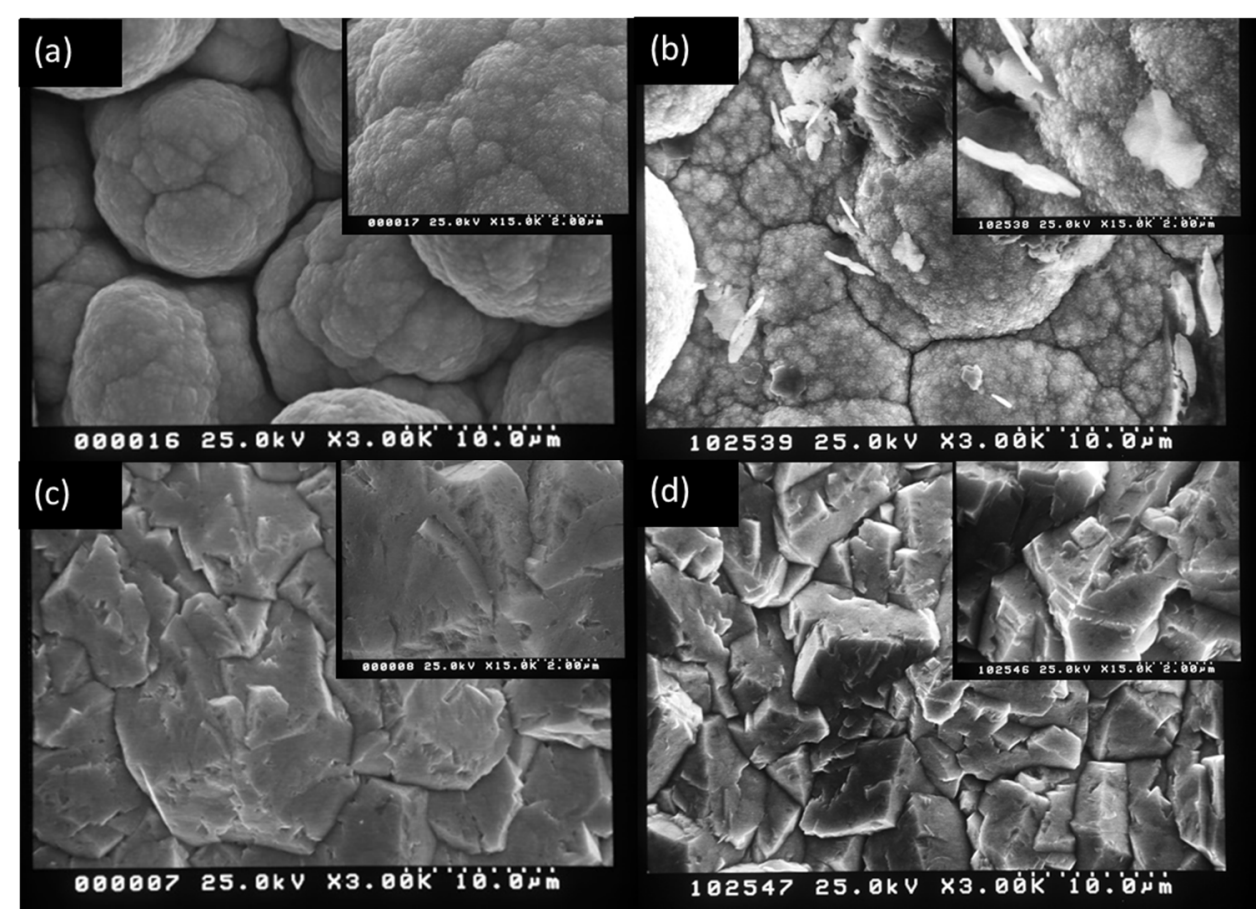

Figure 2. $\mathrm{SEM}$ images of (a) $\mathrm{Ti} / \alpha-\mathrm{PbO}_{2} ;$ (b) Ti $/ \alpha-\mathrm{PbO}_{2}$ used for $5 \mathrm{~h}$; (c) $\mathrm{Ti} / \alpha-\mathrm{PbO}_{2} / \beta-\mathrm{PbO}_{2} ;$ (d) Ti $/ \alpha-$ $\mathrm{PbO}_{2} / \beta-\mathrm{PbO}_{2}$ used for $5 \mathrm{~h}$.

These electrodes were applied to $5 \mathrm{~h}$ of electrochemical decolorization, and then the surface shape was examined. In the case of the $\mathrm{Ti} / \alpha-\mathrm{PbO}_{2}$ electrode, aggregates of organic impurities were observed on the coating surface, and disintegration of fine particles was also observed to some extent (Figure $2 \mathrm{a}, \mathrm{b}$ ). On the other hand, for the used Ti/ $\alpha-\mathrm{PbO}_{2} / \beta-$ $\mathrm{PbO}_{2}$ electrode, it was observed that the fine particles on the coating surface maintained a perfect pyramidal shape and the electrode surface was not changed during the electrolysis (Figure $2 \mathrm{c}, \mathrm{d}$ ). The results indicate it that $\mathrm{Ti} / \alpha-\mathrm{PbO}_{2} / \beta-\mathrm{PbO}_{2}$ composite electrode has better stability, durability, and recyclability.

\subsubsection{XPS Analysis}

We obtained information on the chemical states of the elements in $\mathrm{Ti} / \alpha-\mathrm{PbO}_{2}$ and Ti $/ \alpha-$ $\mathrm{PbO}_{2} / \beta-\mathrm{PbO}_{2}$ electrodes by XPS analysis. The results of the XPS survey show very sharp characteristic peaks of $\mathrm{Pb}$ and $\mathrm{O}$ in both samples, confirming the successful preparation of the $\mathrm{PbO}_{2}$ anode on the titanium plate (Figure 3a). In addition, clear peak shifts of $\mathrm{Pb}_{4 \mathrm{f}}$ and $\mathrm{O}_{1 \mathrm{~s}}$ were observed at the Ti/ $\alpha-\mathrm{PbO}_{2} / \beta-\mathrm{PbO}_{2}$ electrode, compared to the Ti/ $\alpha-\mathrm{PbO}$ electrode (Figure $3 b, c)$. The shift can be attributed to the existence of a strong interaction between $\alpha-\mathrm{PbO}_{2}$ and $\beta-\mathrm{PbO}_{2}$. The XPS spectra of $\mathrm{Pb}_{4 \mathrm{f}}$ are shown in Figure $3 b . \alpha-\mathrm{PbO}_{2}$ has 
two peaks centered on 138.4 and $143.3 \mathrm{eV}$, which correspond to $4 \mathrm{f}_{7 / 2}$ and $4 \mathrm{f}_{5 / 2}$ of $\mathrm{Pb}^{4+}$, and the difference in binding energy was calculated to be about $4.9 \mathrm{eV}$, whereas $\beta-\mathrm{PbO}_{2}$ has peaks centered on 137.5 and $142.4 \mathrm{eV}$, both $4 \mathrm{f}_{7 / 2}$ and $4 \mathrm{f}_{5 / 2}$, had a negative side shift to the $0.9 \mathrm{eV}$, compared to the peak of $\alpha-\mathrm{PbO}_{2}$, respectively $[14,27,30]$. The XPS spectra of $\mathrm{O}_{1 \mathrm{~s}}$ are shown in Figure 3c.

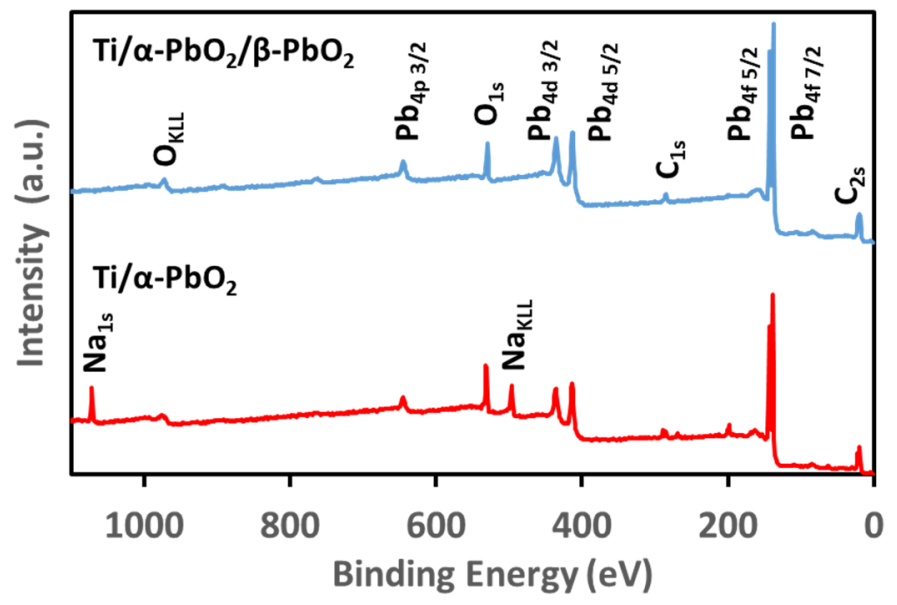

(a)

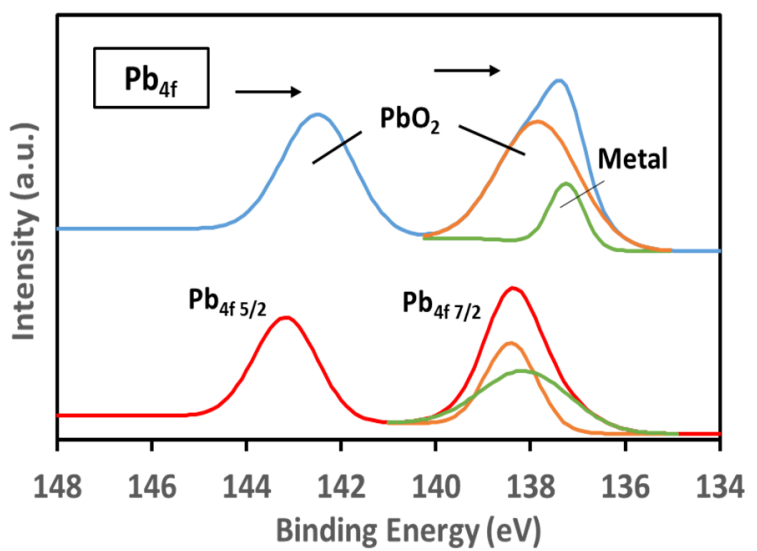

(b)

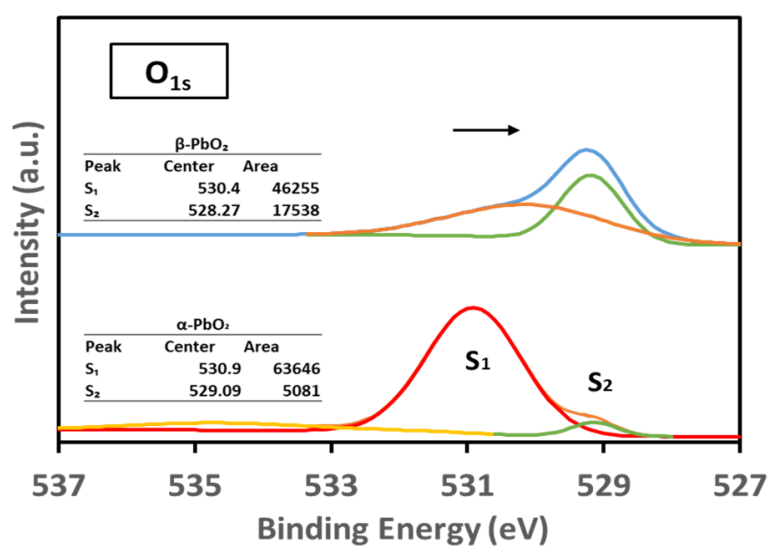

(c)

Figure 3. (a) XPS analysis of Ti/ $\alpha-\mathrm{PbO}_{2} / \beta-\mathrm{PbO}_{2}$ and Ti/ $\alpha-\mathrm{PbO}_{2} ;$ (b) $\mathrm{Pb}_{4 \mathrm{f}}$ spectra of $\mathrm{Ti} / \alpha-\mathrm{PbO}_{2} / \beta-\mathrm{PbO}$ and Ti/ $\alpha-\mathrm{PbO}$; (c) $\mathrm{O}_{1 \mathrm{~s}}$ spectra of $\mathrm{Ti} / \alpha-\mathrm{PbO}_{2} / \beta-\mathrm{PbO}_{2}$ and $\mathrm{Ti} / \alpha-\mathrm{PbO}_{2}$.

The low binding energy component of the $\mathrm{O}_{1 \mathrm{~s}}$ peak near $528.4-533.1 \mathrm{eV}\left(\mathrm{S}_{1}\right)$ is derived from the crystal lattice oxygen $[14,27]$. On the other hand, the high binding energy component of the $\mathrm{O}_{1 \mathrm{~s}}$ peak near $527.2-529.4 \mathrm{eV}\left(\mathrm{S}_{2}\right)$ is attributed to the surface-adsorbed or chemisorbed $\mathrm{OH}^{-}$groups and $\mathrm{H}_{2} \mathrm{O}$ on the oxide. The hydroxyl groups generated on the electrode surface can be trapped in the induced holes to form hydroxyl radicals.

From the results, it is predicted that electron-hole recombination will be suppressed and electrode catalyst efficiency will be improved $[14,26,30]$. By comparing the number of hydroxyl groups $\left(\mathrm{S}_{2}\right)$ present on each electrode surface, $\beta-\mathrm{PbO}_{2}(17,538)$ was larger than $\alpha-\mathrm{PbO}_{2}$ (5081). As shown in Table 1 , the percentage $(\varepsilon \%)$ of the $\mathrm{S}_{2}$ to the total oxygen $\left(\mathrm{S}_{1}+\mathrm{S}_{2}\right)$ for Ti $/ \alpha-\mathrm{PbO}_{2} / \beta-\mathrm{PbO}_{2}$ electrode was $27.5 \%$. Obviously, $\varepsilon \%$ increased, compared to $\mathrm{Ti} / \alpha-\mathrm{PbO}_{2}$ electrode (7.40\%). Therefore, the Ti $/ \alpha-\mathrm{PbO}_{2} / \beta-\mathrm{PbO}_{2}$ electrode was favorable to generate more $\cdot \mathrm{OH}$ radicals and has better electrode catalytic activity. 
Table 1. Analysis of $\mathrm{O}_{1 \mathrm{~s}}$ peaks from electrodes.

\begin{tabular}{|c|c|c|c|c|}
\hline \multirow{2}{*}{ Electrode } & \multicolumn{2}{|c|}{ Binding Energy $(\mathrm{eV})$} & \multirow{2}{*}{$\begin{array}{c}S_{1} \text { Content } \% \\
S_{1} /\left(S_{1}+S_{2}\right)\end{array}$} & \multirow{2}{*}{$\begin{array}{c}S_{2} \text { Content } \% \\
S_{2} /\left(S_{1}+S_{2}\right) \\
\end{array}$} \\
\hline & $\mathrm{S}_{1}$ & $\mathrm{~S}_{2}$ & & \\
\hline $\mathrm{Ti} / \alpha-\mathrm{PbO}_{2}$ & 530.9 & 528.3 & 92.6 & 7.4 \\
\hline $\mathrm{Ti} / \alpha-\mathrm{PbO}_{2} / \beta-\mathrm{PbO}_{2}$ & 530.4 & 529.1 & 72.5 & 27.5 \\
\hline
\end{tabular}

\subsubsection{Electrochemical Performance}

Figure $4 \mathrm{a}$ shows the polarization curves of $\mathrm{Ti} / \alpha-\mathrm{PbO}_{2}$ and $\mathrm{Ti} / \alpha-\mathrm{PbO}_{2} / \beta-\mathrm{PbO}_{2}$ electrodes in $0.50 \mathrm{~mol} \mathrm{~L}^{-1} \mathrm{Na}_{2} \mathrm{SO}_{4}$ solution (scan rate $2 \mathrm{mV} \mathrm{s}^{-1}$ ). The oxygen evolution potentials (OEPs) of prepared electrodes are determined by the extrapolation of current density curve. The OEP at the Ti/ $\alpha-\mathrm{PbO}_{2} / \beta-\mathrm{PbO}_{2}$ electrode $(1.58 \mathrm{~V})$ is more positive than that at the $\mathrm{Ti} / \alpha-\mathrm{PbO}_{2}$ electrode $(0.89 \mathrm{~V})$. High OEP inhibits the oxygen evolution reaction and is very effective for increasing the electrochemical oxidation efficiency of organic pollutants contained in wastewater [31-33]. Therefore, the Ti/ $\alpha-\mathrm{PbO}_{2} / \beta-\mathrm{PbO}_{2}$ electrode may be suitable for decolorizing methylene blue. The oxygen evolution reaction is shown as follows (Equations (6) and (7)):

$$
\begin{gathered}
\mathrm{PbO}_{2}+\mathrm{H}_{2} \mathrm{O} \rightarrow \mathrm{PbO}_{2}(\bullet \mathrm{OH})+\mathrm{H}^{+}+\mathrm{e}^{-} \\
\mathrm{PbO}_{2}(\bullet \mathrm{OH}) \rightarrow 1 / 2 \mathrm{O}_{2}+\mathrm{H}^{+}+\mathrm{e}^{-}+\mathrm{PbO}_{2}
\end{gathered}
$$

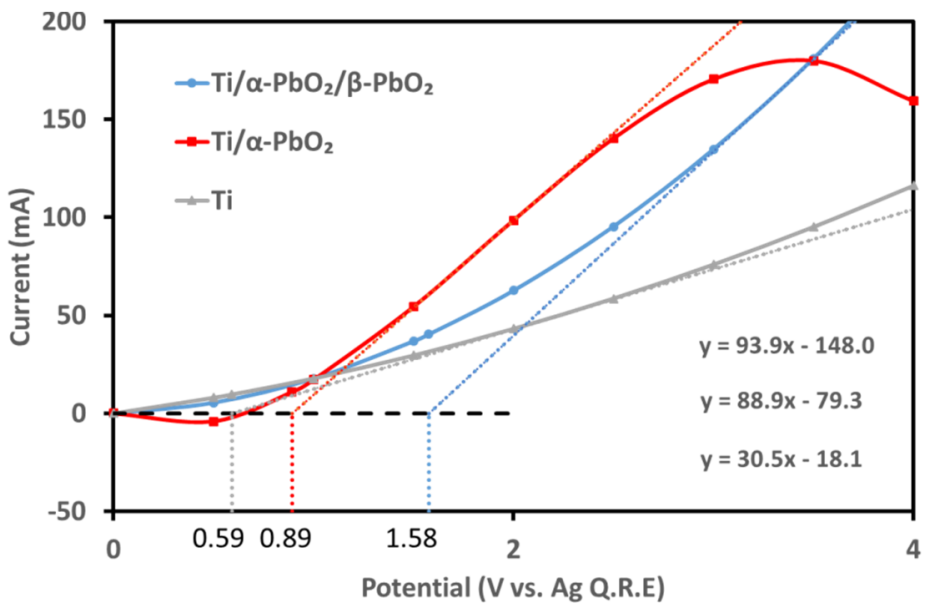

(a)

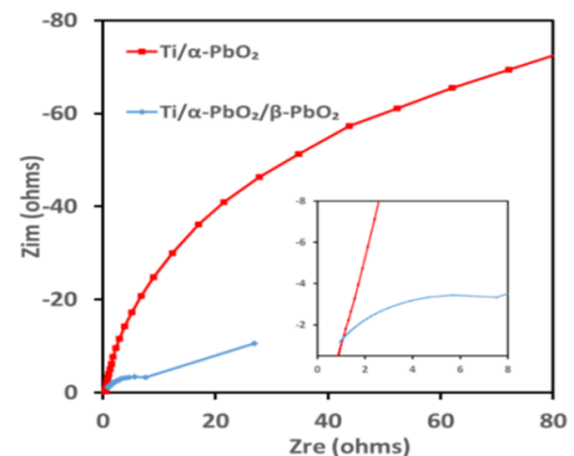

(b)

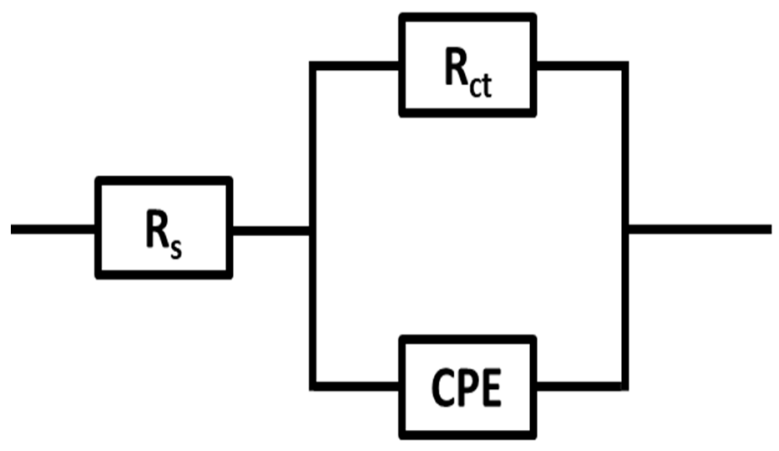

(c)

Figure 4. (a) Polarization curves in $0.50 \mathrm{~mol} \mathrm{~L}^{-1} \mathrm{Na}_{2} \mathrm{SO}_{4}$ at scan rate of $2 \mathrm{mV} \mathrm{s}^{-1}$. (b) Electrochemical impedance spectroscopy in $0.50 \mathrm{~mol} \mathrm{~L}^{-1} \mathrm{Na}_{2} \mathrm{SO}_{4}$ with frequency range of $10^{5} \sim 10^{-1} \mathrm{~Hz}$. (c) Randles equivalent circuit.

The charge transport behaviors of electrodes were investigated using electrochemical impedance spectroscopy (EIS). The interfacial behavior of $\mathrm{Ti} / \alpha-\mathrm{PbO}_{2}$ and $\mathrm{Ti} / \alpha-\mathrm{PbO}_{2} / \beta-$ 
$\mathrm{PbO}_{2}$ electrodes was evaluated in $0.50 \mathrm{~mol} \mathrm{~L}^{-1} \mathrm{Na}_{2} \mathrm{SO}_{4}$ solution in the frequency range of $10^{5} \sim 10^{-1} \mathrm{~Hz}$. Figure $4 \mathrm{~b}$ shows the Nyquist plots acquired from the EIS measurement of the $\mathrm{Ti} / \alpha-\mathrm{PbO}_{2}$ and $\mathrm{Ti} / \alpha-\mathrm{PbO}_{2} / \beta-\mathrm{PbO}_{2}$. As shown in the plot, one-semicircle traces can be obtained for each electrode, which reveals single time constant behaviors for the relation of charge transfer resistance. Generally, the radius of the semicircle is related to the charge transfer resistance, and the smaller the arc radius, the faster the electron transfer at the interface [30-33]. The Randles equivalent circuit as displayed in Figure 4c is frequently employed to simulate the electrochemical characteristics on electrode surface/solution interface. There are mainly Rs, CPE, and $R_{c t}$ in the equivalent circuit. Rs usually presents the resistance of electrolyte and active material, which is considered as the junction with the real axis at the high-frequency end; CPE (constant phase element) represents the capacitive behavior on electrode surface; $R_{c t}$, the diameter of the semicircle, represents charge transfer resistance at the $\mathrm{PbO}_{2}$ film/solution interface. $1 / 2 \mathrm{R} c t$ of $\mathrm{Ti} / \alpha-\mathrm{PbO}_{2} / \beta-\mathrm{PbO}_{2}(5.51)$ is smaller than that of $\mathrm{Ti} / \alpha-\mathrm{PbO}_{2}$ (91.7), indicating that the improved electrochemical performance of the $\mathrm{Ti} / \alpha-\mathrm{PbO}_{2} / \beta-\mathrm{PbO}_{2}$ [31-34].

\subsection{Optimization of $M B$ Decolorization Conditions}

\subsubsection{UV-Vis Spectra}

Figure 5a shows the change in the UV-Vis spectra of MB during the electrochemical decolorization process using $\mathrm{Ti} / \alpha-\mathrm{PbO}_{2} / \beta-\mathrm{PbO}_{2}$ electrode. Strong absorption peaks were observed at 292 and $664 \mathrm{~nm}$, which are derived from the absorbance of the major chromophore group of $\mathrm{MB}[17,19]$. The absorbance peak $\left(0.03 \mathrm{mg} \mathrm{L}^{-1}\right)$ decreased with the electrochemical decolorization treatment time and disappeared completely after $30 \mathrm{~min}$. The facts indicate it that the MB chromophore group has been completely removed $[10,11]$. Besides, a blue shift in absorbance was observed during the electrochemical decolorization process. This is universal in other bleaching approaches and means the appearance of by-products in the MB chromophore group [33-35]. It was confirmed that the $\mathrm{Ti} / \alpha-\mathrm{PbO}_{2} / \beta-$ $\mathrm{PbO}_{2}$ electrode functioned as a good catalyst for electrical decolorization. In the present work, a sharp absorbance peak at $664 \mathrm{~nm}$ was used to show the degree of decolorization. Figure $5 b$ compares the decolorization efficiency of $\mathrm{MB}$ using $\mathrm{Ti} / \alpha-\mathrm{PbO}_{2}$ and Ti $/ \alpha-\mathrm{PbO}_{2} / \beta-$ $\mathrm{PbO}_{2}$ electrodes as anodes by electrochemical method in $0.05 \mathrm{~mol} \mathrm{~L}^{-1} \mathrm{Na}_{2} \mathrm{SO}_{4}$ solution containing $3 \mathrm{mg} \mathrm{L}^{-1} \mathrm{MB}$ with the voltage at $20 \mathrm{~V}$, current density $8-12 \mathrm{~mA} \mathrm{~cm}^{-2}$, and initial $\mathrm{pH}$ value 6.0.

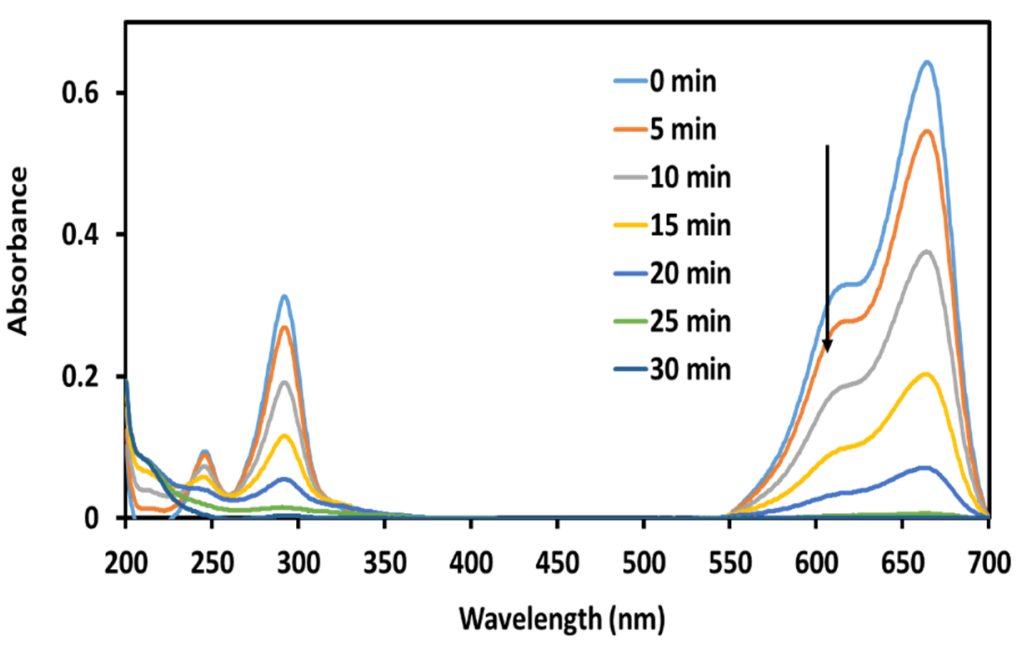

(a)

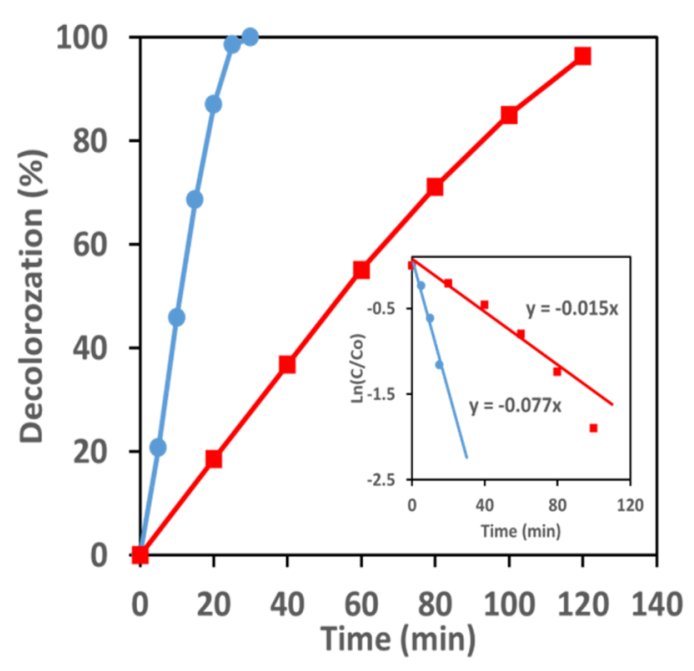

(b)

Figure 5. (a) UV-Vis spectra of $\mathrm{MB}$ during the electrochemical oxidation process with $\mathrm{Ti} / \alpha-\mathrm{PbO}_{2} / \beta-\mathrm{PbO}_{2}$. (b) Decolorization efficiency of $\mathrm{MB}$ with $\mathrm{Ti} / \alpha-\mathrm{PbO}_{2} / \beta-\mathrm{PbO}_{2}$ (blue) and $\mathrm{Ti} / \alpha-\mathrm{PbO}_{2}$ (red). $\mathrm{Na}_{2} \mathrm{SO}_{4}$ electrolyte: $0.05 \mathrm{~mol} \mathrm{~L}-1$; reaction time: $2 \mathrm{~h}$; electrode distance: $3 \mathrm{~cm}$; initial $\mathrm{pH}$ : 6.0; reaction temperature: $25^{\circ} \mathrm{C}$; $\mathrm{MB}: 3 \mathrm{mg} \mathrm{L}{ }^{-1}$; and cell voltage: $20 \mathrm{~V}$. 
The methylene blue decolorization efficiency was obtained as follows (Equation (8)). Also, the semi-log graphs of MB decolorization fit the pseudo-first-order model, as described in Equation (9):

$$
\begin{gathered}
\text { MB decolorization efficiency }(\%)=\left(C_{0}-C_{t}\right) / C_{0} \times 100 \\
\operatorname{Ln}\left(C_{t} / C_{0}\right)=k
\end{gathered}
$$

where $C_{0}$ and $C_{t}$ are absorbance values in $664 \mathrm{~nm}$ of the $\mathrm{MB}$ solution at the initial and the given time $t$, respectively, and $k$ is the pseudo-first-order rate constant $\left(\mathrm{min}^{-1}\right)$. The result shows it that $\mathrm{MB}$ can be completely removed on $\mathrm{Ti} / \alpha-\mathrm{PbO}_{2} / \beta-\mathrm{PbO}_{2}$ electrodes after $30 \mathrm{~min}$, whereas, on $\mathrm{Ti} / \alpha-\mathrm{PbO}_{2}$ electrodes it required $120 \mathrm{~min}$ under the same conditions. The decolorization processes for both electrodes followed the pseudo-first-order model [36,37], and the kinetics curves are shown in the inset. The rate constant of $\mathrm{MB}$ by Ti $/ \alpha-\mathrm{PbO}_{2} / \beta-$ $\mathrm{PbO}_{2}$ electrode was $0.077 \mathrm{~min}^{-1}$, which was about 5 times that of $\mathrm{Ti} / \alpha-\mathrm{PbO}_{2}$ electrode $\left(0.015 \mathrm{~min}^{-1}\right)[38,39]$.

\subsubsection{Effect of Initial MB Concentration}

Figure 6 shows the decolorization efficiencies of $\mathrm{MB}$ as a function of different initial $\mathrm{MB}$ concentrations. It can be observed that the MB decolorization rates decreased with the increase of initial MB concentration. The main reason could be ascribed to it that the treated $\mathrm{MB}$ amounts were almost the same even if the MB initial concentration increased and the competing between $\mathrm{MB}$ and its intermediates occurred for the active sites. Hence, we applied the kinetics constants of MB removal to express the competition for hydroxyl radicals between MB and its intermediates. When the MB concentration was high $\left(>15 \mathrm{mg} \mathrm{L}^{-1}\right)$, the reaction could not follow the first-order model, because the rate-determining step was mass transfer process (diffusion). From Fig inset, the k values were 0.098, 0.053, 0.036, 0.024, 0.016 , and $0.020 \mathrm{~min}^{-1}$ for the initial MB concentration of $3,6,9,12,15$, and $30 \mathrm{mg} \mathrm{L}^{-1}$, respectively, which further proved the increased competition between $\mathrm{MB}$ and its intermediates for hydroxyl radicals with increasing initial concentration. When initial MB concentration increased from 3 to $15 \mathrm{mg} \mathrm{L}^{-1}$, the decolorization efficiency $\mathrm{k}$ changed as the initial concentration increased. This can be explained by the rapid reaction of hydroxyl radicals with $\mathrm{MB}$ molecules at the electrode at the voltages without oxygen evolution. Thus, a relatively high concentration of $\mathrm{MB}\left(9 \mathrm{mg} \mathrm{L}^{-1}\right)$ was chosen as the optimum initial concentration $[38,39]$.

\subsubsection{Effect of Applied Cell Voltage}

The applied current density is deeply involved in the control of hydroxyl radical generation, which is an important factor in the electrochemical decolorization of MB. Figure 7 shows the effect of applied current density on the electrochemical performance. From the results in Figure 7a, it can be found that when the applied voltages increased from 10 to $20 \mathrm{~V}$, the MB removal efficiencies increased from $48.2 \%$ to $88.7 \%$, as well as apparent rate constants increased from 0.011 to $0.027 \mathrm{~min}^{-1}$, respectively. It can be deduced that increasing voltage had a positive influence on the decomposition of $\mathrm{MB}$ in the range 5 20 V. The enhanced decolorization and degradation of MB at larger current densities could have resulted in higher hydroxyl radical production. In Figure 7b, a current density after 10 min increased at the voltage of $30 \mathrm{~V}$, however, only a slight increase occurred after 10 min when the voltage increased from 5 to $20 \mathrm{~V}$. Thus, the increased oxygen evolution as the side reaction prevented the degradation of MB. The increase in the electrochemical decolorization efficiency with an increase in current density is a typical phenomenon for processes controlled by mass transfer. Therefore, the cell voltage of $20 \mathrm{~V}$ could be chosen for the optimum condition (corresponding to current density $0.05-0.10 \mathrm{~A} \mathrm{~cm}^{-2}$ ), owing to the energy cost. 


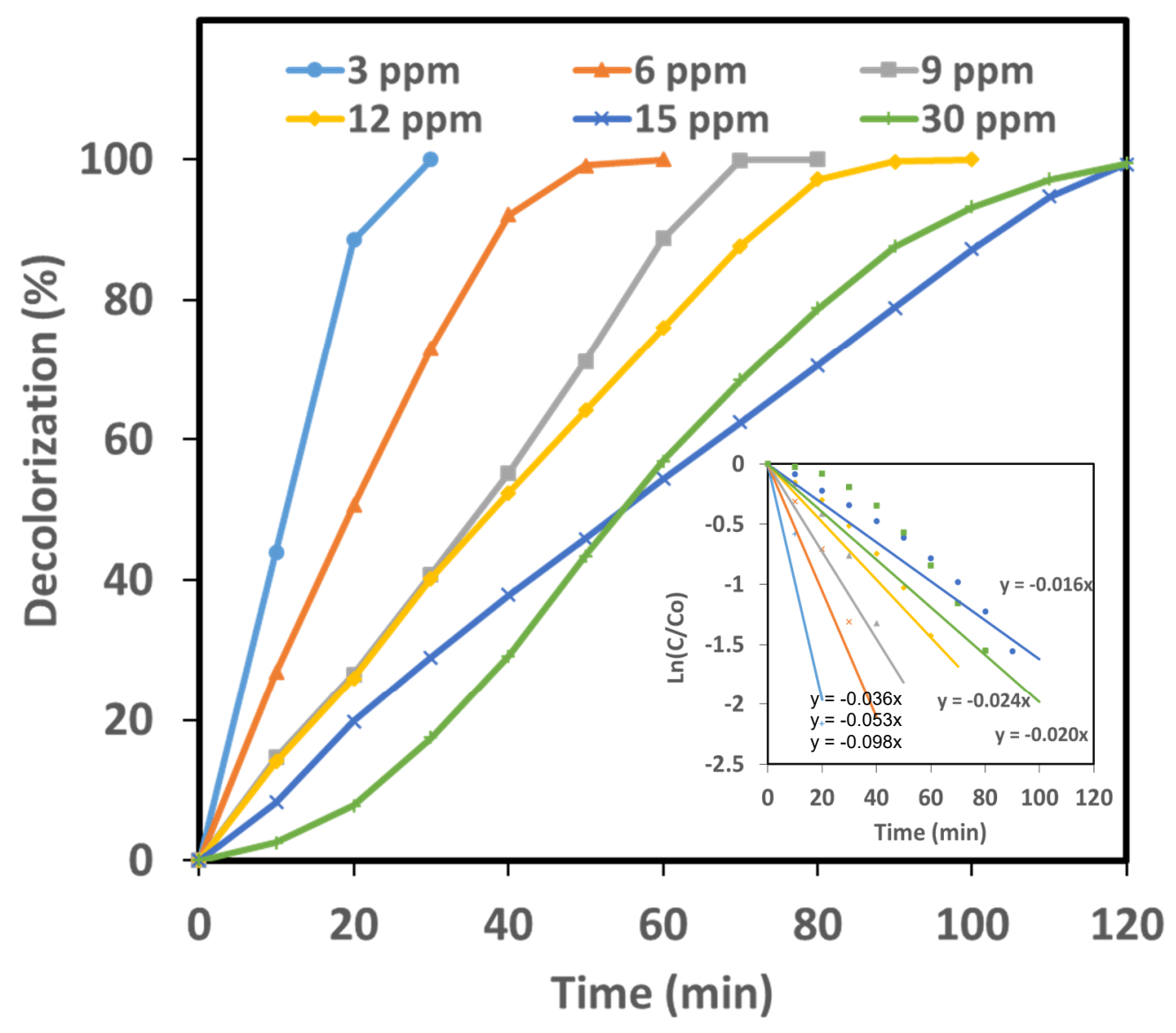

Figure 6. Effects of $\mathrm{MB}$ concentration on decolorization efficiency. $\mathrm{Na}_{2} \mathrm{SO}_{4}$ electrolyte: $0.05 \mathrm{~mol} \mathrm{~L}^{-1}$; reaction time: $2 \mathrm{~h}$; electrode distance: $3 \mathrm{~cm}$; initial $\mathrm{pH}$ : 6.0 ; reaction temperature: $25{ }^{\circ} \mathrm{C}$; $\mathrm{MB}$ : $3 \sim 30 \mathrm{mg} \mathrm{L}^{-1}$; cell voltage: $20 \mathrm{~V}$.

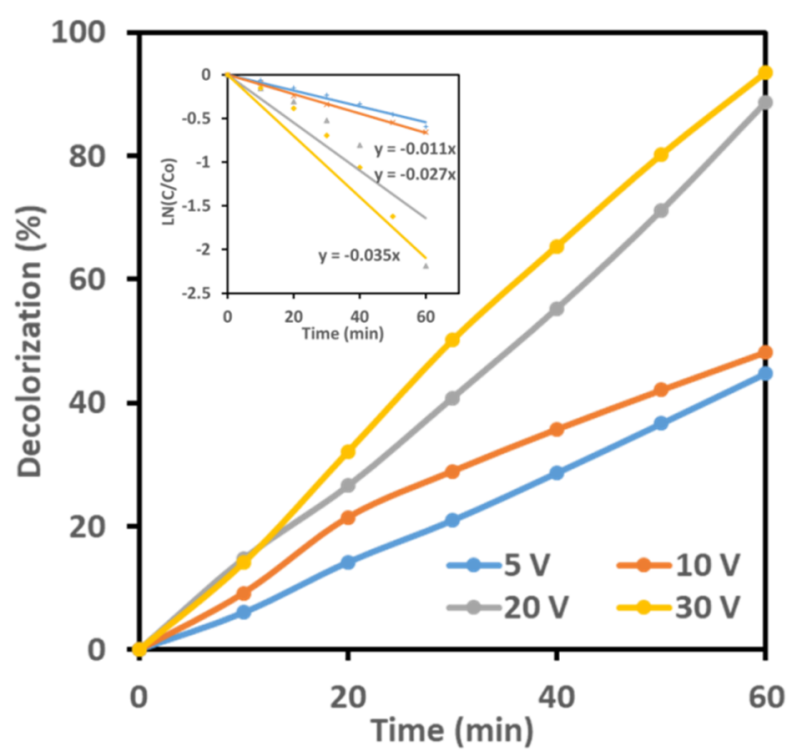

(a)

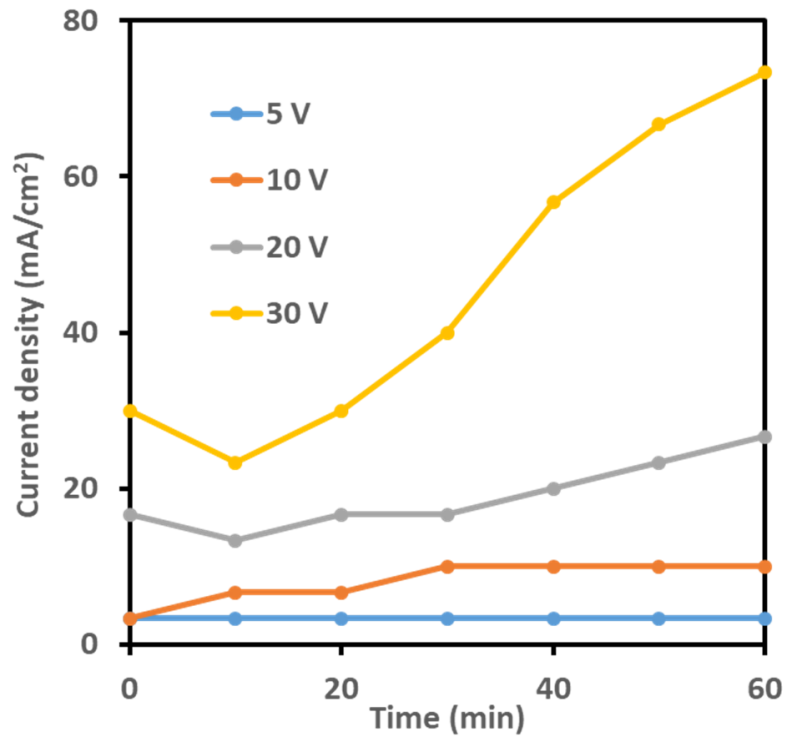

(b)

Figure 7. (a) Effects of cell voltage on decolorization efficiency. $\mathrm{Na}_{2} \mathrm{SO}_{4}$ electrolyte: $0.05 \mathrm{~g} \mathrm{~L}^{-1}$; reaction time: $1 \mathrm{~h}$; electrode distance: $3 \mathrm{~cm}$; initial $\mathrm{pH}$ : 6.0; reaction temperature: $25^{\circ} \mathrm{C}$; $\mathrm{MB}: 9 \mathrm{mg} \mathrm{L}^{-1}$; cell voltage: $5 \sim 30 \mathrm{~V}$. (b) Current density change vs. treatment times. 


\subsubsection{Effect of Initial $\mathrm{pH}$}

The initial $\mathrm{pH}$ of the solution is a significant element of the electrochemical decolorization process. In Figure 8, the effect of initial $\mathrm{pH}$ on $\mathrm{MB}$ decolorization was investigated. The $\mathrm{NaOH}$ and $\mathrm{H}_{2} \mathrm{SO}_{4}$ solutions were used for $\mathrm{pH}$ adjustment to obtain a given $\mathrm{pH}$ value. It was found from Figure 8a that the decolorization efficiencies of MB under acid or alkaline conditions were better than those obtained under neutral conditions.

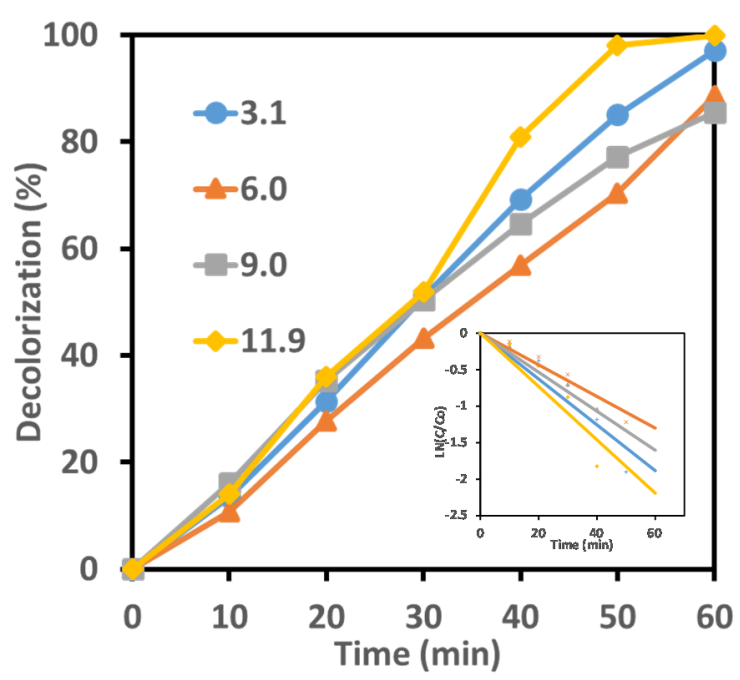

(a)

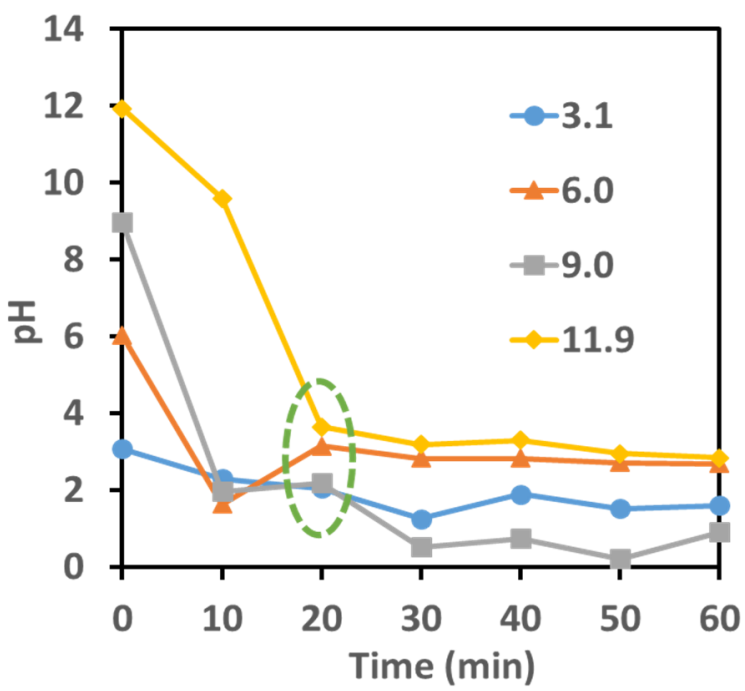

(b)

Figure 8. (a) Effects of $\mathrm{pH}$ on decolorization efficiency. $\mathrm{Na}_{2} \mathrm{SO}_{4}$ electrolyte: $0.05 \mathrm{~mol} \mathrm{~L}^{-1}$; reaction time: 1 h; electrode distance: $3 \mathrm{~cm}$; initial $\mathrm{pH}$ : 3.1-11.9; reaction temperature: $25^{\circ} \mathrm{C}$; MB: $9 \mathrm{mg} \mathrm{L}^{-1}$; cell voltage: $20 \mathrm{~V}$. (b) $\mathrm{pH}$ change vs. treatment times.

The $\mathrm{k}$ values of $\mathrm{pH} 11.9$ and $\mathrm{pH} 3.1$ were 0.015 and $0.009 \mathrm{~min}^{-1}$, respectively, which were larger relative to those at $\mathrm{pH}$ 6.0. The results may be attributed to the oxygen evolution side reaction, electrostatic attraction, and the molecular $\mathrm{MB}$ structure. At lower $\mathrm{pH}$ (under acidic conditions), oxygen evolution is more strongly suppressed, leading to faster and more effective decolorization. At higher $\mathrm{pH}$ (under basic conditions), the electrostatic attraction is strong, because $\mathrm{MB}$ is present primarily in the form of anions, making it very difficult to adsorb to the electrode surface. In addition, the generation of hydroxyl radicals is effective in the presence of hydroxide ions. However, as shown in Figure 8b, the sample solution pHs changed to acidic conditions after $20 \mathrm{~min}$. This change is derived from the generation of hydrogen ions during the electrochemical process. As a consequence, the difference in initial $\mathrm{pH}$ did not significantly affect the continuous decolorization, the initial $\mathrm{pH} 6.0$ was the optimum $\mathrm{pH}$ value for considering the practicality and environment.

\subsubsection{Effect of Initial $\mathrm{Na}_{2} \mathrm{SO}_{4}$ Concentration}

Electrolyte concentration can be considered to be an important factor in the electrochemical decolorization process, since it greatly fluctuates the current density. Figure 9a shows the effect of electrolyte concentration on the decolorization efficiency of MB. The treatments were investigated with $0.01,0.05,0.07,0.09$, and $0.15 \mathrm{~g} \mathrm{~L}^{-1} \mathrm{Na}_{2} \mathrm{SO}_{4}$ electrolyte. The results show it that an increase in electrolyte concentration significantly accelerates the decomposition of $\mathrm{MB}$, and as the electrolyte concentration increases from $0.01 \mathrm{~g} \mathrm{~L}^{-1}$ to $0.15 \mathrm{~g} \mathrm{~L}^{-1}$, the decolorization efficiency of MB increases proportionally (Figure 9a). Obviously, high electrolyte concentrations promoted the decolorization and decomposition of MB. Figure $9 \mathrm{~b}$ shows almost constant current densities during treatment time. The $\mathrm{Na}_{2} \mathrm{SO}_{4}$ concentration had little effect on the fluctuation of current density. 


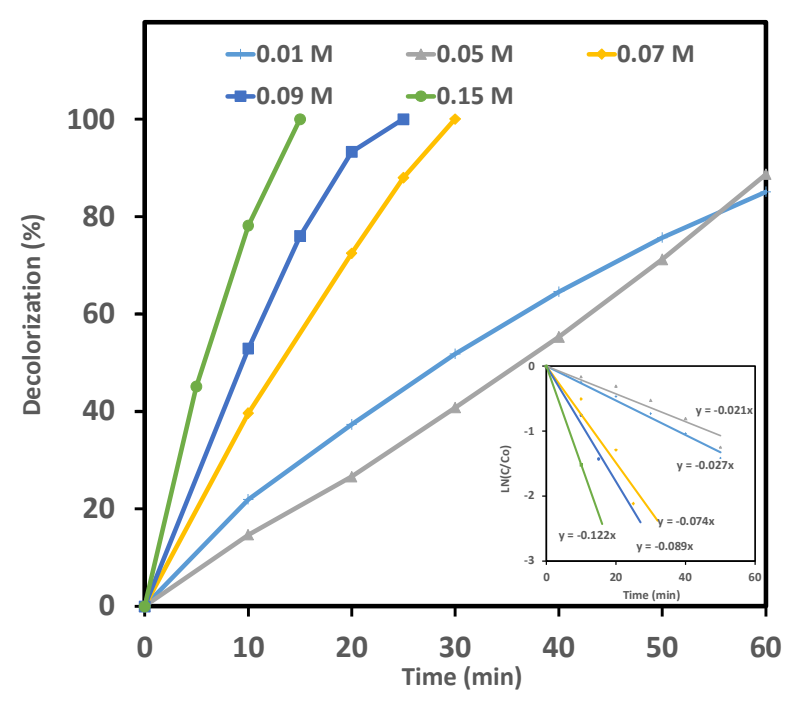

(a)

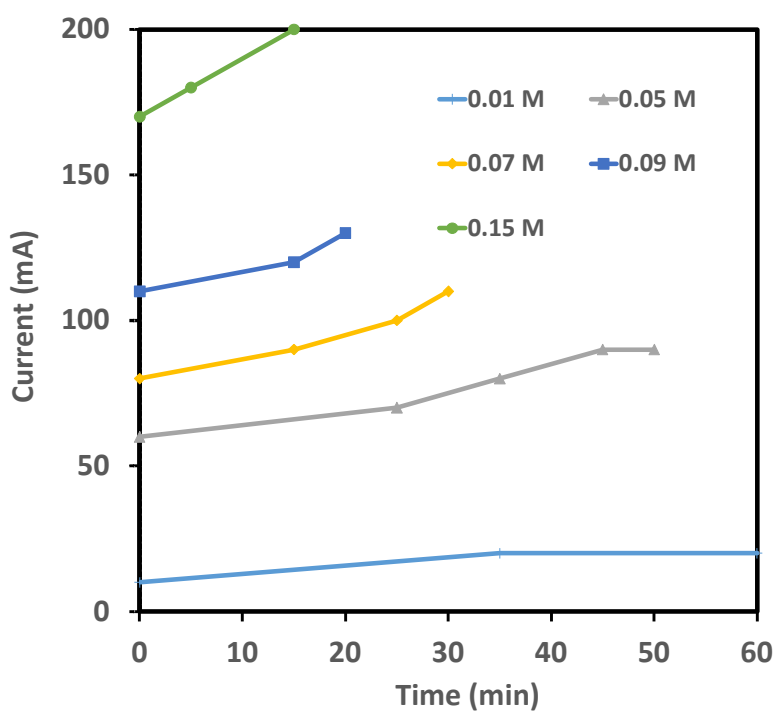

(b)

Figure 9. (a) Effects of concentration of $\mathrm{Na}_{2} \mathrm{SO}_{4}$ on decolorization efficiency. $\mathrm{Na}_{2} \mathrm{SO}_{4}$ electrolyte: $0.01 \sim 0.15$ mol L ${ }^{-1}$; reaction time: $1 \mathrm{~h}$; electrode distance: $3 \mathrm{~cm}$; initial $\mathrm{pH}$ : 6.0; reaction temperature: $25^{\circ} \mathrm{C}$; MB: $9 \mathrm{mg} \mathrm{L}{ }^{-1}$; and cell voltage: $20 \mathrm{~V}$. (b) Current vs. treatment times.

\subsection{Electrode Stability}

The recyclability is a very significant parameter for assessing electrode stability, durability, and economic applicability. Therefore, the electrochemical stability of the $\mathrm{Ti} / \alpha-$ $\mathrm{PbO}_{2} / \beta-\mathrm{PbO}_{2}$ electrode was estimated by conducting a recycling test for $\mathrm{MB}$ decolorization. $\mathrm{Ti} / \alpha-\mathrm{PbO}_{2} / \beta-\mathrm{PbO}_{2}$ electrode exhibited the similar decolorization efficiency for $\mathrm{MB}$ after five cycles to that of first treatment. Figure 10 shows that the XRD of Ti/ $\alpha-\mathrm{PbO}_{2} / \beta-\mathrm{PbO}_{2}$ electrode before and after repeated electrode. It was confirmed that the surface crystal structure could be retained, although the intensity of $\beta-\mathrm{PbO}_{2}$ peaks reduced slightly. This result demonstrates it that the $\mathrm{Ti} / \alpha-\mathrm{PbO}_{2} / \beta-\mathrm{PbO}_{2}$ electrode can be repeatedly used as an excellent electrode.

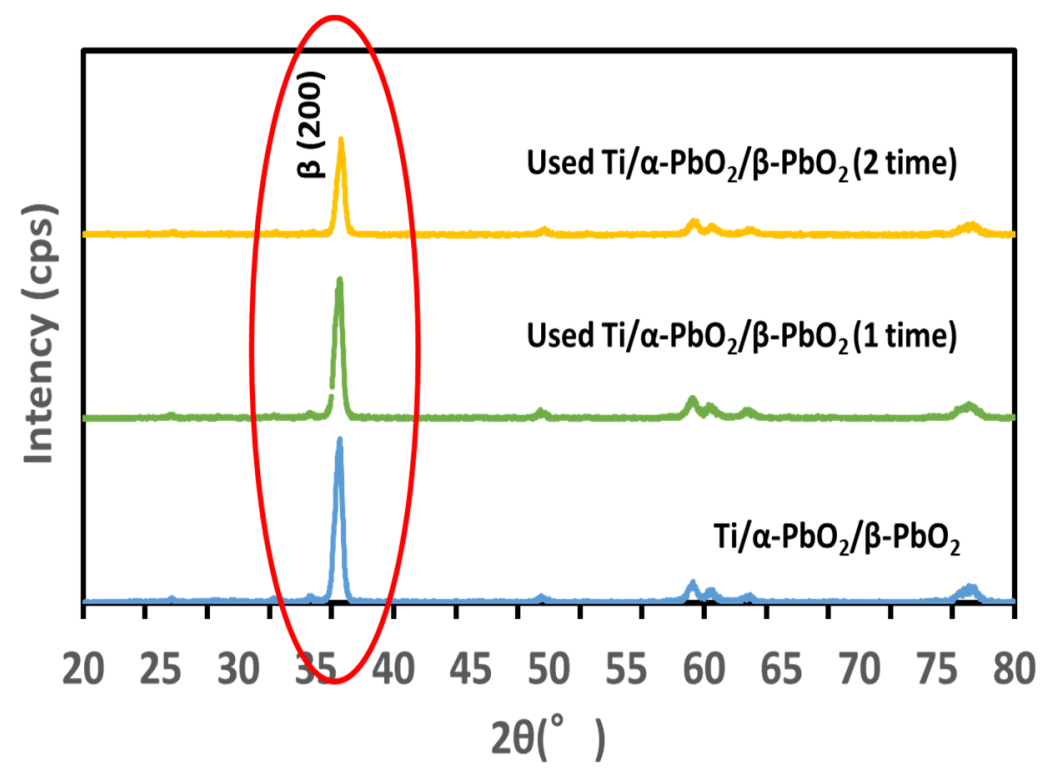

Figure 10. $\mathrm{XRD}$ of $\mathrm{Ti} / \alpha-\mathrm{PbO}_{2} / \beta-\mathrm{PbO}_{2}$ before and after five cycles. $\mathrm{Na}_{2} \mathrm{SO}_{4}$ electrolyte: $0.01 \mathrm{~mol} \mathrm{~L}{ }^{-1}$; reaction time: $1 \mathrm{~h}$; electrode distance: $3 \mathrm{~cm}$; initial $\mathrm{pH}$ : 6.0; reaction temperature: $25^{\circ} \mathrm{C}$; $\mathrm{MB}: 0.05 \mathrm{~g} \mathrm{~L}^{-1}$; and cell voltage: $20 \mathrm{~V}$. 


\section{Conclusions}

The operating conditions for the electrochemical decolorization of $\mathrm{MB}$ with $\mathrm{Ti} / \alpha-$ $\mathrm{PbO}_{2} / \beta-\mathrm{PbO}_{2}$ were optimized. The optimum operating parameters for the electrochemical decolorization of $\mathrm{MB}$ at $\mathrm{Ti} / \alpha-\mathrm{PbO}_{2} / \beta-\mathrm{PbO}_{2}$ composites were as follows: $\mathrm{Na}_{2} \mathrm{SO}_{4}$ elec-

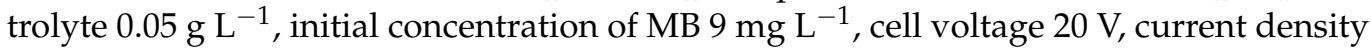
0.05-0.10 $\mathrm{A} \mathrm{cm}^{-2}$, and $\mathrm{pH}$ 6.0. The $\mathrm{MB}$ dye with $9 \mathrm{mg} \mathrm{L}^{-1}$ concentration could be completely decolorized with $\mathrm{Ti} / \alpha-\mathrm{PbO}_{2} / \beta-\mathrm{PbO}_{2}$ after a treatment time of less than one hour.

Author Contributions: Conceptualization, M.A.I.M. and S.K.; methodology, M.F.; validation, M.F. and I.T.; formal analysis, M.F.; investigation, I.T.; resources, H.K.; data curation, G.Y.; writingoriginal draft preparation, G.Y.; writing-review and editing, I.T.; visualization, H.K.; supervision, S.K.; project administration, S.K. All authors have read and agreed to the published version of the manuscript.

Funding: The present research was partly supported by Grant-in-Aid for Scientific Research (B) 21H03642 from the Ministry of Education, Culture, Sports, Science, and Technology of Japan.

Conflicts of Interest: The authors declare no conflict of interest. All experiments were conducted at Mie University. Any opinions, findings, conclusions or recommendations expressed in this paper are those of the authors and do not necessarily reflect the view of the supporting organizations.

\section{References}

1. Yurtsever, A.; Sahinkaya, E.; Aktaş, Ö.; Uçar, D.; Çinar, Ö.; Wang, Z. Performances of anaerobic and aerobic membrane bioreactors for the treatment of synthetic textile wastewater. Bioresour. Technol. 2015, 192, 564-573. [CrossRef]

2. Chanwala, J.; Kaushik, G.; Dar, M.A.; Upadhyay, S.; Agrawal, A. Process optimization and enhanced decolorization of textile effluent by Planococcus sp. isolated from textile sludge. Environ. Technol. Innov. 2019, 13, 122-129. [CrossRef]

3. Kornmüller, A.; Cuno, M.; Wiesmann, U. Selective ozonation of polycyclic aromatic hydrocarbons in oil/water-emulsions. Water Sci. Technol. 1997, 35, 57-64. [CrossRef]

4. Yıldırım, A.Ö.; Gül, Ş.; Eren, O.; Kuşvuran, E. A Comparative study of ozonation, homogeneous catalytic ozonation, and photocatalytic ozonation for C.I. Reactive Red 194 azo dye degradation. CLEAN-Soil Air Water 2011, 39, 795-805. [CrossRef]

5. Nidheesh, P.; Gandhimathi, R.; Ramesh, S. Degradation of dyes from aqueous solution by Fenton processes: A review. Environ. Sci. Pollut. Res. 2013, 20, 2099-2132. [CrossRef] [PubMed]

6. Chen, Y.; Lin, J.; Chen, Z. Remediation of water contaminated with diesel oil using a coupled process: Biological degradation followed by heterogeneous Fenton-like oxidation. Chemosphere 2017, 183, 286-293. [CrossRef]

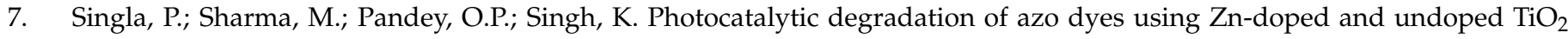
nanoparticles. Appl. Phys. A 2014, 116, 371-378. [CrossRef]

8. Neon, M.H.K.; Islam, M.S. $\mathrm{MoO}_{3}$ and Ag co-synthesized $\mathrm{TiO}_{2}$ as a novel heterogeneous photocatalyst with enhanced visiblelight-driven photocatalytic activity for methyl orange dye degradation. Environ. Nanotechnol. Monit. Manag. 2019, $12,100244$.

9. Teymori, M.; Khorsandi, H.; Aghapour, A.A.; Jafari, S.J.; Maleki, R. Electro-Fenton method for the removal of Malachite Green: Effect of operational parameters. Appl. Water Sci. 2020, 10, 39. [CrossRef]

10. Wang, C.; Huang, Y.K.; Zhao, Q.; Ji, M. Treatment of secondary effluent using a three-dimensional electrode system: COD removal, biotoxicity assessment, and disinfection effects. Chem. Eng. J. 2014, 243, 1-6.

11. Shih, Y.J.; Huang, Y.H.; Huang, C.P. Oxidation of ammonia in dilute aqueous solutions over graphite-supported $\alpha$ - and $\beta$-lead dioxide electrodes $\left(\mathrm{PbO}_{2} @ \mathrm{G}\right)$. Electrochim. Acta 2017, 257, 444-454. [CrossRef]

12. Awad, H.S.; Galwa, N.A. Electrochemical degradation of Acid Blue and Basic Brown dyes on $\mathrm{Pb} / \mathrm{PbO}_{2}$ electrode in the presence of different conductive electrolyte and effect of various operating factors. Chemosphere 2005, 61, 1327-1335. [CrossRef]

13. Wang, Y.; Shen, Z.Y.; Li, Y.; Niu, J.F. Electrochemical properties of the erbium-chitosan-fluorine-modified $\mathrm{PbO}_{2}$ electrode for the degradation of 2,4-dichlorophenol in aqueous solution. Chemosphere 2010, 79, 987-996. [CrossRef]

14. Zheng, Y.H.; Su, W.Q.; Chen, S.Y.; Wu, X.Z.; Chen, X.M. Ti/ $\mathrm{SnO}_{2}-\mathrm{Sb}_{2} \mathrm{O}_{5}-\mathrm{RuO}_{2} / \alpha-\mathrm{PbO}_{2} / \beta-\mathrm{PbO}_{2}$ electrodes for pollutants degradation. Chem. Eng. J. 2011, 174, 304-309. [CrossRef]

15. Vazquez-Gomez, L.; de Battisti, A.; Ferro, S.; Cerro, M.; Reyna, S.; Martínez-Huitle, C.A.; Quiroz, M.A. Anodic oxidation as green alternative for removing diethyl phthalate from wastewater using $\mathrm{Pb} / \mathrm{PbO}_{2}$ and $\mathrm{Ti} / \mathrm{SnO} \mathrm{O}_{2}$ anodes. CLEAN-Soil Air Water 2012, 40, 408-415. [CrossRef]

16. Yahiaoui, I.; Aissani-Benissad, F.; Fourcade, F.; Amrane, A. Response surface methodology for the optimization of the electrochemical degradation of phenol on $\mathrm{Pb} / \mathrm{PbO}_{2}$ electrode. Environ. Prog. Sustain. Energy 2012, 31, 515-523. [CrossRef]

17. Li, G.; Yip, H.Y.; Wong, K.H.; Hu, C.; Qu, J.; Wong, P.K. Photoelectrochemical degradation of Methylene Blue with beta-PbO 2 electrodes driven by visible light irradiation. J. Environ. Sci. China 2011, 23, 998-1003. [CrossRef]

18. Sakib, A.A.M.; Masum, S.M.; Hoinkis, J.; Islam, R.; Molla, M.A.I. Synthesis of CuO/ZnO nanocomposites and their application in photodegradation of toxic textile dye. J. Compos. Sci. 2019, 3, 91. [CrossRef] 
19. Zhang, W.; Li, H.; Tang, J.; Lu, H.; Liu, Y. Ginger straw waste-derived porous carbons as effective adsorbents toward Methylene Blue. Molecules 2019, 24, 469. [CrossRef] [PubMed]

20. Yanagi, G.; Furukawa, M.; Tateishi, I.; Katsumata, H.; Kaneco, S. Electrochemical colorization of methylene blue in solution with metal doped $\mathrm{Ti} / \alpha, \beta-\mathrm{PbO}_{2}$ mesh electrode. Sep. Sci. Technol. 2021. [CrossRef]

21. Duan, X.Y.; Ma, F.; Yuan, Z.X.; Chang, L.M.; Jin, X.T. Electrochemical degradation of phenol in aqueous solution using $\mathrm{PbO}_{2}$ anode. J. Taiwan Inst. Chem. Eng. 2013, 44, 95-102. [CrossRef]

22. Devilliers, D.; Thi, M.T.D.; Mahe, E.; Le Xuan, Q. Cr(III) oxidation with lead dioxide-based anodes. Electrochim. Acta 2003, 48, 4301-4309. [CrossRef]

23. Aquino, J.M.; Pereira, G.F.; Rocha-Filho, R.C.; Bocchi, N.; Biaggio, S.R. Electrochemical degradation of a real textile effluent using boron-doped diamond or $\beta-\mathrm{PbO}_{2}$ as anode. J. Hazard. Mater. 2011, 192, 1275-1281. [CrossRef]

24. Aquino, J.M.; Rocha-Filho, R.C.; Ruotolo, L.A.M.; Bocchi, N.; Biaggio, S.R. Electrochemical degradation of a real textile wastewater using b-PbO 2 and DSA ${ }^{\circledR}$ anodes. Chem. Eng. J. 2014, 251, 138-145. [CrossRef]

25. Chen, Z.; Yu, Q.; Liao, D.H.; Guo, Z.C.; Wu, J. Influence of nano- $\mathrm{CeO}_{2}$ on coating structure and properties of electrodeposited $\mathrm{Al} / \alpha-\mathrm{PbO}_{2} / \beta-\mathrm{PbO}_{2}$. Trans. Nonferrous Met. Soc. 2013, 23, 1382-1389. [CrossRef]

26. Bian, X.; Xia, Y.; Zhan, T.; Wang, L.; Zhou, W.; Dai, Q.; Chen, J. Electrochemical removal of amoxicillin using a $\mathrm{Cu}_{\text {doped }} \mathrm{PbO}_{2}$ electrode: Electrode characterization, operational parameters optimization and degradation mechanism. Chemosphere 2019, 233, 762-770. [CrossRef]

27. Xinyu, S.; Xiaoyue, D.; Feng, X.; Limin, C. Fabrication of three-dimensional networked $\mathrm{PbO}_{2}$ anode for electrochemical oxidation of organic pollutants in aqueous solution. J. Taiwan Inst. Chem. Eng. 2019, 100, 74-84.

28. Li, X.; Pletcher, D.; Walsh, F.C. Electrodeposited lead dioxide coatings. Chem. Soc. Rev. 2011, 40, 3879-3894. [CrossRef]

29. Yao, Y.; Ren, B.; Yang, Y.; Huang, C.; Li, M. Preparation and electrochemical treatment application of Ce-PbO $2 / \mathrm{ZrO}_{2}$ composite electrode in the degradation of acridine orange by electrochemical advanced oxidation process. J. Hazard. Mater. 2019, 361, 141-151. [CrossRef]

30. Shmychkova, O.; Luk'yanenko, T.; Amadelli, R.; Velichenko, A. Physico-chemical properties of $\mathrm{PbO}_{2}$-anodes doped with $\mathrm{Sn}^{4+}$ and complex ions. J. Electroanal. Chem. 2014, 717, 196-201. [CrossRef]

31. Wang, X.; Wu, Q.; Ma, H.; Ma, C.; Yu, Z.; Fu, Y.; Dong, X. Fabrication of $\mathrm{PbO}_{2}$ tipped $\mathrm{Co}_{3} \mathrm{O}_{4}$ nanowires for efficient photoelectrochemical decolorization of dye (reactive brilliant blue KN-R) wastewater. Sol. Energy Mater. Sol. Cells 2019, 191, $381-388$. [CrossRef]

32. Zhang, Y.; He, P.; Jia, L.; Li, C.; Liu, H.; Wang, S.; Zhou, S.; Dong, F. Ti/ $\mathrm{PbO}_{2}-\mathrm{Sm}_{2} \mathrm{O}_{3}$ composite based electrode for highly efficient electrocatalytic degradation of alizarin yellow R. J. Colloid Interface Sci. 2019, 533, 750-761. [CrossRef]

33. Li, J.; Li, M.; Li, D.; Wen, Q.; Chen, Z. Electrochemical pretreatment of coal gasification wastewater with Bi-doped $\mathrm{PbO}_{2}$ electrode: Preparation of anode, efficiency and mechanism. Chemosphere 2020, 248, 126021. [CrossRef]

34. Yao, Y.; Teng, G.; Yang, Y.; Ren, B.; Cui, L. Electrochemical degradation of neutral red on $\mathrm{PbO}_{2} / \alpha-\mathrm{Al}_{2} \mathrm{O}_{3}$ composite electrodes: Electrode characterization, byproducts and degradation mechanism. Sep. Purif. Technol. 2019, 227, 115684. [CrossRef]

35. Del Nero, J.; de Araujo, R.E.; Gomes, A.S.L.; de Melo, C.P. Theoretical and experimental investigation of the second hyperpolarizabilities of methyl orange. J. Chem. Phys. 2005, 122, 104506. [CrossRef]

36. Li, H.Y.; Chen, Y.; Zhang, Y.H.; Han, W.Q.; Sun, X.Y.; Li, J.S.; Wang, L.J. Preparation of Ti/PbO ${ }_{2}-S n$ anodes for electrochemical degradation of phenol. J. Electroanal. Chem. 2013, 689, 193-200. [CrossRef]

37. Bhatia, D.; Datta, D.; Joshi, A.; Gupta, S.; Gote, Y. Adsorption study for the separation of isonicotinic acid from aqueous solution using activated carbon $/ \mathrm{Fe}_{3} \mathrm{O}_{4}$ composites. J. Chem. Eng. Data 2018, 63, 436-445. [CrossRef]

38. Zhang, Q.; Guo, X.; Cao, X.; Wang, D.; Wei, J. Facile preparation of a Ti/ $\alpha-\mathrm{PbO}_{2} / \beta-\mathrm{PbO}_{2}$ electrode for the electrochemical degradation of 2-chlorophenol. Chin. J. Catal. 2015, 36, 975-981. [CrossRef]

39. Dai, Q.; Zhou, J.; Meng, X.; Feng, D.; Wu, C.; Chen, J. Electrochemical oxidation of cinnamic acid with $\mathrm{Mo}_{\text {modified }} \mathrm{PbO}_{2}$ electrode: Electrode characterization, kinetics and degradation pathway. Chem. Eng. J. 2016, 289, 239-246. [CrossRef] 